\title{
MYSTICAL SPARKS IN THE SAHIFEH SAJADIEH AND ITS STRATEGIC ROLE IN ISLAMIC MYSTICISM
}

\author{
Mehrdad Aghaei ${ }^{1}$ \\ Farshid Hadi $^{2}$
}

\begin{abstract}
Sahifah Sajjadiyah as the first influence of the infallible prayer on the darkness of polytheism and mysticism, this legacy of the infallible Imam is a special and unique book containing prayers to Imam Sajjad (PBUH), full of ethical and mystical themes. , Like a beacon of light for seekers of the path of Islamic righteousness, and as a home for the mystics of the Vale and the guidance of the lost mystics in the Wadi. This study aims to analyze and analyze the monotheistic and mystical doctrines of the Sajadiyyah by descriptive-analytic method, and to examine the reason for the prayerfulness of this Bible as well as the monotheism from Imam Zayn al-Abidine's viewpoint and the path of Islamic mysticism. It has been studied and studied in Sahifah, as the Sahajadiyah is regarded as the primary basis for the foundation of the Islamic mysticism and the monotheistic way of life, and it can certainly play a key strategic role in Sahifah. The Imam (PBUH) deals with Islamic mysticism and its positive reflections in this field and refers to that
\end{abstract}

Imam Hammam as Imam al-Abidin and Mersdal Elkin and Alarfyn introduced to the world.

Keywords: Imam Sajjad (AS), Sahifah Sajadiyeh, Prayer, Monotheism, Islamic Sufism.

\section{Introduction}

Sahifah Sajadiyyah is a book with the themes of prayer that due to the inappropriate conditions when the Imam was living, it was not possible to educate the public openly, so the Imam declared Sahifah as a prayer and indirectly instructed the people. "Sahifah Sajadiyeh is one of the treasures of Islamic heritage and a source for rhetorical education, ethics and literature in the Islamic world. Due to the great importance of this book, the great scholars have called it "Okt al-Qur'an", "Gospel of Ahl al-Bayt" and "Zebor al-Muhammad". This book invites Muslims to abstraction, spirituality, self-purity and removal from selfishness, greed, greed, and other evil traits, and also calls for a relationship with

\footnotetext{
${ }^{1}$ Department of Arabic Language and Literature, University of Mohaghegh Ardabili. Email: Almehr55@yahoo.com.

${ }^{2}$ Young Researchers Club, Bilesavar Branch, Islamic Azad University, Bilesavar, Iran.

Email: hadi_236@yahoo.com
} 
God, the Creator of the Universe. "(Fadavi Ardestani, 2005: 152)

Sahifah Sajadiyyah is a collection of prayers which is very valid in terms of content and content and is the only work after the Quran that has been available as a book from the late first and early second century AH. While Nahj al-Balagha became a book in the fourth century (Barzegar, 23: 233), including the merits of the Imam Sajjad (AS), it is enough that "Imam Zayn al-Abidine wrote it and Baqir al-Alum wrote it and his imam was honest. Hears, that the day is not remembered, the speaker, writer and the like are gathered. The scholars of the Holy Religion of Islam have described this book as "The Holy Qur'an" and Nahj alBalagha as "The Holy Qur'an", that is, as the Exalted God of the Holy Qur'an has spoken in the language of Prophet Khatam alAnbiyah and Nahjul Balagheh. Also, Sahifah, whose words have been extracted from the source of divine knowledge, is in the language of the two Ali (pbuh). (Faiz alIslam, 1997: 404)

The record now in our hands reaches Najmuddin Baha al-Sharif, who received it in $514 \mathrm{AD}$ in the month of Rabi'i al-Aswah in the form of the document quoted in the first verse. This record contains 54 prayers, which are narrated in 54 verses by Ahmad ibn Muslim Motahhari. (Garmaroodi, 2008: 31)

\section{Research Background}

Numerous books and articles have been written about the Sajadiyah Sajadiyyah, but none have raised the question that the Sajadiyyah of Imam was a usher in Islamic mysticism, and in fact it can be said that the prayers of Imam Sajjad (AS) With the themes rich in pure mysticism, the school of Islamic mysticism is in the first century AH. Examples of related articles are:

1- The Mystical Effects of Prayer in Sajafieh Sajadiyeh-Ebrahimi Mehdi-The Religious Thought Journal 13-Winter 2005

2- The Relationship between Mysticism and Politics in Sajafieh Sajadieh - Barzegar Ebrahimi - Journal of Religious Thought No. 12 - Fall 2004

3- Ethical Principles in Sajadieh Sahapieh - Pahlavan Mansour - Journal of Spacecraft No. 8 - Fall 2005

4- An Introduction to the Sajadiyyah Sahifiyyah-Si Chitik WilliamHadith Science Journal-3 (41) Fall 85

5- The Glory of Sajjadiyyah Interpretation-Khanjani Ali Avast-The Religious Thought Magazine - No. 15 Summer 84

6- Literature of Imam Sajjad and AS Sajadiyyah-Mir Ghaderi Sayyed Fazlollah - Religious Thoughts Issue 15 Summer 84 .

2 Imam Sajjad (AS) and Sahifah Sajjadiyyah 
Her name is Mubarak Ali, and her most famous nickname is Zayn al-Abidine and Sajjad. Her lifetime was fifty-seven years, and she was born on the fifteenth day of her thirty-eighth year. Hazrat Sajjad (AS) has a father like Hussein and his mother is the daughter of King Yazdgerd of Iran.

The life of Imam Sajjad (AS) was one of the most difficult and oppressive times for the Ahlul-Bayt and the Imams, and many restrictions were imposed by the Umayyads on the infallible Imams. Therefore, it was not possible for Imam Sajjad (AS) to convene discussions, commentaries, jurisprudence and other sciences. The Prophet has expressed many pure Islamic teachings in the form of Sahifa prayers, and we find that this book includes the most delicate topics of theology, ontology, the unseen world and the messengers of the prophets, the position of the Prophet, and the Prophet's Prophet, and virtues., The special manners of the devil, the devil's ways of misleading the people, paying attention to the manifestations of the Lord's power, remembering the various blessings of God and the duty of thanksgiving, the Lord's self-sacrificing verses, prayerful conduct, recitation, remembrance, prayer and worship, and dozens Another important issue.

The importance of the Sajjadiyah is because the infallible Imam, like Prophet Sajjad, prayed to his God with these prayers in secret. The Sahifah, also referred to as AlMuhammad's Zebra, is of particular interest to both the speaker and the audience. In addition to the deep content and supreme themes that lie behind these prayers, the Sajadiyah Sahifah has particular documentary strength.

Imam Sajjad (AS), due to the inappropriate circumstances of his time, could not publicly dissuade people from moral deviations, and teach them to avoid such deviations. Because the disgraceful Umayyad government impeded the divine activities of the Imam, and the people did not turn to the Imam (AS) for fear of this corrupt government to learn the divine and vital issues. They even refused to meet the Prophet. Therefore, the Imam (AS) said all the human needs of that day and until now in the form of prayer and indirectly educated the people to save them from going astray and thereby convey their divine mission to the people. He said: "My crafts garden Bghan Bmkaydh and install Msaydh and contact network of associates visited Lee Rayth and Azba to Zba' Saba Ltrydth expectations Lanthaz Alfrsh Lfrysth Vhv Yzhr Lee pep Almlq and Ynzrny Alhnq Ali humans." Perhaps the rogue tyrant who has tried to hunt me down with a vicious and ever-searching trap to hunt me down and, like a predatory animal that sits in ambush, lurking in ambush, worries about the opportunity to hunt Grab it, but the enemy 
enjoys flattery and has a grudge. (Ansarians, 2013: 330)

In this rise of the Imam's prayer, he refers to the corrupt Umayyad agents who obstructed his activities and sought every opportunity to eliminate the Imam who saw in their paths, as they posed a serious danger to the Imam. The government saw itself for several days. They would see the people around the Imam ring and go to the Imam for lessons, discussions, and religious laws, and he would become less attractive to him and endanger the Umayyad rule. Therefore, the Umayyad government took great action against the Imam (as). Thus, the people were scattered around the Imam for fear of this corrupt government and were deprived of that source of divine grace that could save them from the grooves of the path. And the imam inevitably stated the teachings in the form of prayer.

\section{Prayer structure of Sahifah Sajadiyeh}

Prayer in the word means "Neda" and in the customary terms, attention to God and seeking His mercy is poverty, dwelling and humility, and is also praised, praised, praised, and exalted for the transcendent; And praise is also a kind of request and responsibility, according to the Prophet (peace be upon him) : (The best of the supplication is my propaganda and the prophets of the prophets by me, and there is no God but Allah alone. ) (Madani, 2007: 53)

Prayer is a means of communication with God. Man attends to the righteousness in times of distress, suffering, hardship, need and need, and expresses his pain to the unique Creator, which is the same prayer. As God has said: (Say what my Lord cares about you without your prayers.) (Ferghan / 77). Say: My Lord is not worthy of you if your prayer is not; You have denied (the revelations of Allah and the Prophets), and will take your life and will not be separated from you.

In other words, "it is impossible to know the essence of prayer without regard to the attributes of human cognition. Man is known more for his body than for his body, which is crystallized in his actions. Prayer is the most serious, purest, and most powerful way of communicating human beings to the Almighty Creator, relying on divine vibrant power. Prayer is the best means of communication between the Creator and the Creator, and is one of the ways to purify the self and to polish the inherent pearls of humans. Prayer is a tool for a better understanding of humanity. Prayer is not the only tool but a dialogue between the lover and the beloved and this mystery and need with the Creator of Being must be known to lead to knowledge, and this cannot be done unless the mystery and need we express in 
the language Understand perfectly. " (Shining, 2012: 27)

In order to know one's God, one must first know the value of the potentialities of one's self, knowing one's self-restraint from contamination, to learn the way to communicate with God, by praying correctly to the potential talents within oneself. And God willing to act. In this way:

Prayer in the morning and oh the night is the key to treasure in this way.(Hafez, 2004: 283)

Man must first know himself and know his worth, then know his God. To realize the value of the potentialities in Himself and to protect His rebellious soul from contamination, and to learn the way to communicate with God, through this communication and the means of praying to the potential talents within Himself. To act correctly and godly. "Prayer is the benchmark of faith, and man's relationship with God is mine. Whoever considers him present and observant, do not turn away from his prayers with him, and whoever knows him as capable and competent, let him have no other means than his own, and fear him who knows him. His kindness and mercy calm the hearts of the believers and his generosity calm the souls of the believer. God's friends have enjoyed conversations with him, and they have long forgotten, regretted, and regret. Sympathy and depression in prayer are signs of grief and sadness. " Read me to meet you. Those who turn away from my worship with arrogance will soon enter hell with humiliation.) According to Rumi:

What to do about knowing what to do for a child, what to do for a child or a wife

Crazy about both worlds Whats the crazy part of both of them?

(Molavi, 1984: 1977/492)

Because man is God in nature, in the ups and downs of life, in the difficult things and in the difficulties, where his hope is cut off from everything and everyone and feels that he has no choice, his essence, he He directs him to the One God to communicate with him, and in this way he speaks with God in the language of the heart. If Imam Sajjad (AS) over the prayer I said: "or rich Alaghnya' of Nahnu Badk between Scanning and Anna Afghari Alfqra' click Fajbr Faqtna Bvsk Vela Tqt Rja'na Bmnk Ftkvn Height Ashqyt I Astsd Beck and respect me Astrfd Fzlk Fali I Hynyz Mnqlbna Nk and But now, with Babak Suhanki, the synagogue has a conspicuous occasion, and it is in the hands of al-Sufi, the Wisdom of Al-Kashani, 51 (13). O most needy needy, now we have your servants in front of you, and I am the poorest of the poor in your presence. Redeem our poverty and impotence to the extent possible, and do not cut off our hope of deterrence, that if you do so, it will be miserable to the research of the one who wishes himself good, and who 
seeks grace and favor, Deprived. To whom shall we turn at this time before thee, and deprived of thy mercy, whither our way shall fall, pure and isolated. We are the helpless ones who have made it obligatory to accept their prayers, and we are the oppressors who have promised to eliminate their oppression.

Prayer alone is not enough for prayer to be appreciated, because God has placed the wisdom of the universe on the basis of toys and has set out specific solutions for the emergence of any particular causal phenomenon and for any problem. On the one hand, it provided man with reason and thought to help him find solutions to problems and to reach the goal, and on the other hand, he had two kinds of material and spiritual causes. Man should act with the help of his godly mind and consult with knowledgeable and expert people, hoping from the beginning of each work to the end by praying and resorting to the grace of God, asking him to do what he wants. To achieve the desired goal and result. The result is that prayer alone is not a $100 \%$ solution to problems and can not be replaced by work, effort, planning, and expertise, but can complement it. "(Hadith) Eleanor, 1408: 110)

Imam Zayn al-Abidine's (AS) prayer for his parents is one of the most brilliant Islamic education laws prescribed for family reform and their prosperity and for the spread of love and respect among family members. "It is natural that if the family is reformed the whole society will be reformed, and if the family is corrupt the whole society will be corrupted because the family is the main pillar of social structure. Imam Sajjad (pbuh) said in prayer 24: "God have mercy upon Muhammad, his servant and prophet and his pure family, and bestow upon them the best of mercy, peace, and blessings. O God, my Father, grant me with dignity and salutation from you, O Most Merciful. " (Fadavi Ardestani, 2005: 95 and 96)

\section{Islamic Sufism and Sahifah Sajadiyeh}

Mysticism or knowledge in the word means knowledge, and in myth, mysticism is the knowledge of the heart that is obtained through discovery and intuition. Mysticism is divided into two practical and theoretical parts: the practical mysticism (Sufism) expresses human relations and duties with oneself, with society and with God, and the seeker must go through the authorities and homes, passing through the possible existence and Fanny achieves transcendent existence. But theoretical mysticism is the secret discovery and knowledge that liberates human beings from their limits, and reaches existence beyond its own limited universe. (Tehrani, 1980: 16, 17) In other words, in explaining the purpose of Islamic mysticism, it can be said that "Theoretical mysticism is called the science 
of principles, and the practical mysticism of the received science, and the purpose of Islamic mysticism, is to know God in person and intuitively. The perfection of the mystic is to attain the right, not to understand the right, and to meet the right and attain it, it is necessary to travel, or to pass through homes and stages and authorities. "(Khalid, 2002: 43) In other words, Islamic mysticism" knowledge And it is the ontological knowledge such as the observation that the human being (the mystic) is all-knowing, intuitive, and without the need for any preliminaries, and this knowledge is an individual and non-transferable knowledge to the other. "(Madani, 2008: 51)

Concerning the origins of Islamic mysticism and its time, it should be said that "in Islamic teachings and in the practical life of the Prophet (peace be upon him) and the Imams (as) the things that can theoretically inspire subtle and precise mystical meanings It brings a lot of spiritual joy and a myriad of spiritual and spiritual struggles and movements. " (Motahari, 2006: 22)

The Holy Quran is one of the first sources of Islamic mysticism from within the Crimean verses. The customary verb, with all its derivations, is found in the 15 chapters of the Holy Quran and in the 22 verses, all of which refer to the concept of cognition. In verse 83 of Surah Al-same-as follows: (Vaza Smva we see more Ynhm Rasul people who granting me my Rfva
Mma Aldm Amna Haq Yqulvn infrastructure Faktbna with Alshahdyn) and each time they hear the verses revealed to the Prophet of Islam, to cross The eyes of their eyes, full of tears of joy over the truth they have received, say that our Lord believed, so write us with witnesses and witnesses of truth, among the companions of Muhammad. This Crimean verse refers to the knowledge of the truth, which is in fact the knowledge of God Almighty, and the mystics are among the witnesses, or martyrs. "The mystics, upon the success of Prophet Haqq, succumbed to the Divine Book, succeeding in understanding its heavenly concepts, and following its knowledge, fulfilled its commandments, thereby overcoming the darkness of ignorance and oppression of self and unbelief and the home. The heart was illuminated by the light of the Qur'an, and with this luminous light of divine light they lived among the people. "(Ansari 1387: 14) As God has said: ). And we gave him a light that lives in the light of it. "By the blessing of this light, they came to certainty, and thereafter they became adorned with ethical and practical virtues and gained the right to life by Tayeeb." (Ibid.: 14) As the Qur'an has pointed out:

After the Holy Qur'an, Nahj alBalagha is the second source of Islamic mysticism, which is incomparable with that of the Holy Qur'an and the quotations of Amir al-Mu'minin (AS) among human 
words. The Nahj al-Balagha is like an ocean in which mysticism and mystical sciences are like fountains against which they melt. It can be said that Nahj al-Balagha is a cornerstone of the words of a complete human being, both in theoretical and practical mysticism, complete mystic, though not all of the mystical material and mystical expressions of Imam Ali (as) are mentioned in Nahj al-Balagha, But Nahj alBalaghah itself is the mirror of the whole school of mysticism and truth. Imam Ali (AS) points out in this sermon 109: "The composition of al-Nubi and the area of alRasali and various al-Malaikahs, and the mines of al-'Almi and Ianabi al-Hikimi of Nasserna and the al-Mutbah of al-Nawat alUmm al-Umm al-Umm al-Umm al-Umm alRumi The landing-place of missionaries and angels, and the mine of knowledge and springs of wisdom, our helpers and lovers await the mercy of God and our enemies and haters await the punishment of God (Dashti, 2011: 146) Imam, if there is science and if there is a mysticism, is found in the family of revelation and mission ie Ali and his children.

After the Holy Quran and Nahjul Balagheh, Sahifah Sajadiyyah is the second work of the infallible source of the great source of Islamic mysticism, which has been left out of the eyes of many elders and mystics, and it is with great regret that the famous mystics They ignore this source and gain some Greek and Western views and opinions. Sahifah Sajjadiyah, as the first influence of the prayers of the Infallible, shines on the darkness of courtesy and mysticism, which Imam Sajjad (AS) founded upon the foundations of Islamic mysticism. Imam Sajjad begins the first prayer of Sahifah with the praise of God Almighty "thank God for the first tribe and the last for the last time". The blessed being that is first, without being first before him and last, without being last after him (Ansarian, 2013: 11)

\section{Monotheistic themes of Sahifah Sajadiyya with a mystical approach}

The word monotheism means to act in the sense of being unique. The root of this word is "unity" and means solitude and hence the unit refers to something that has no component. The term monotheism in theological discourse means monotheism, one of the tenets of the Islamic religion, as well as of all Abrahamic religions. The importance of this principle is because many Islamic theologians believe that the principles of the Islamic religion are based on the principle of monotheism. A believer must confess to the oneness of God with his heart and tongue, and only know him as his idol and never associate with him, because idolatry with God is a great oppression and an unforgivable sin( Loghman / 13). O my son, do not associate with God, because 
idolatry is a great injustice. "Tawhid has always been at the forefront of the speech of the prophets and God's authorities, and the first title in theological discussion is the question of the unity of God and in the Qur'an hundreds of verses about Tawhid, and against it the idolatry of the greatest sins and the basis of deviations and deviations and causing all sins. It is unforgivable. The Prophet (peace and blessings be upon him) said to one of his companions, Abdullah ibn Mas'ud: "Ayatollah Tasraq Balla had an objective and a high degree of self-esteem and dignity and dignity for the sake of God." However, they will sabotage you with a saw, cut to pieces, or be hanged or burned with fire. " (Mohammadi Eshthardi, 2009: 28)

Monotheism is the oneness of God and the basic principle of religion is Islam and precedes other principles. And believing in the oneness of God is a preference over other. "From the point of view of Imam Sajjad (AS), faith in the one God and the sincere belief in monotheism and purity of any kind of idolatry and atheism is essential for the ideal human being and those who succeed in this way must say thanks and praise to the Prophet. And praise be to God who has given us His knowledge and made known to us. And he opened to us some of the infinite doors to his robbery, and by his grace as a sincere supreme in his unity, he guided us away from the shirk, atheism, and doubt. " (Farzaneh, 2005: 78)
Imam Sajjad (AS) has identified

God in humanity and has introduced it as a requirement for mystical knowledge of God, including love. "Thought about God is only an integral part of human life and profound effects. It's not about human life. Sahifah Sajadiyyah as one of the important sources of Shi'a that is taken from the word of Imam Sajjad (AS). It contains precise themes about knowing God and human interaction with God. The words expressed in the form of prayer can be found with a bit of thoughtful, mystical, and romantic knowledge of God "(Ishaqaqi, 2001: 5).

According to the teachings of the Holy Quran and the Infallible, the foundation of the religion of Tawheed is "First of all, it is full of praise to God, and to the Almighty God." God is the witness of His oneness according to the implication of the verse. Laws, the beginnings and creation of creation, heaven and hell and ... only the divine truth $\mathrm{D}$ relies. The truth of monotheism is the basis of the religion of God. And of course the monotheism that Islam introduces is that Allah is the Exalted of all things in the world and there is no Exalted in all the worlds except Him (Sharifani, 2005: 44).

In an excerpt from the Imam's (AS) prayer in the Sajjadiyyah concerning monotheism and the fight against Shirk, we read: "Al-Hamidah Allah our Prophet, the Prophet, the Prophet, and the Prophet (peace 
be upon him)." In Tawhidiyyah, Wajibanbani Mani al-Alhadi and alShaykhiyyah in Umarah. And thanks be to God for revealing His existence to us, for inspiring us with thanksgiving, and opening the gates of knowledge to His Lord, and guiding us to his unity in devotion, and avoiding deviation from religion and doubt in His command. (Ansarian, 2013: 14) In this speech, Imam Sajjad (AS), after giving thanks to God and reminding him of his blessings, says: "God has guided us in the light of these blessings and capitals in the light of his monotheism and in the light of Such sincerity has made us proud of all manifestations of idolatry, atheism and doubt." (Mohammadi Eshthardi, 2009: 30)

God has introduced Himself to humanity and has recognized and acknowledged the good of God and His attributes, even though full knowledge of God is beyond human capacity. As the Prophet (peace and blessings be upon him) said: "We are your true mysticism" as we should not have known (Allameh Majlesi, 1984: 146).

In the seventeenth prayer of unity and oneness of the God My $\neg$ Khvanym: 'O my Bzlk and Amm nectar Balrbvbyh Lake, and Lake Akhls Balvhdanyh, and Adah Lake veritable Albvdyh and Astzhr Beck advertisement against al-Ulum Alrbanyh knowledge. " The gods subject to this prayer will appoint ten who testify to your Lord,
460

sincerely unite you, and enmity with the devil in the truth of your servitude, and help you to understand the science of religion against him. (Ansariyyah, 2013: 99) In this prayer, there are three things about monotheism and monotheism, monotheism in the pure nature of God and monotheism, devotion away from Satan, which Imam Sajjad (pbuh) calls upon the Divine Prayer to follow the leaders of these three sects. Maintain its stronghold and stronghold and put it in the light of the monotheism and its branches, and also ask God to help Satan overcome his knowledge of the communal sciences.

As we read in paragraph 3 of Prayer 47, " You are God and there is no God but You, the one who is the unique individual " To Allah, there is no god but you, a single, single, and unique God (Ibid: 286), as well as in verse 36 of Sura Nallah about the monotheism of worship and devotion to the pure essence of God: "It is inexcusable in all Ummah!" It is the consecration of Allah and the avoidance of it ". We have sent a messenger in every nation to worship the One God, and to avoid the rebellion. So the point of all the prophets' plan was to worship only God and avoid worshiping non-God. (Mohammadi Eshthardi, 2009: 34)

At the beginning of the 47th day of prayers, the Imam says: "He is Allah, the Almighty, the Almighty, and $\mathrm{He}$ is the 
Almighty, the Almighty." You, the God who is not a god, do not lack karim and dignity. God is not in you and a god other than you, taller and higher than anything and ultimately capable. (Ansarian, 2013: 287) As is evident above the above prayers refers to the monotheism and attributes of God, such as infinite mercy and power beyond which it is superior and superior to all that exists. As he has said in the sequence of this prayer: "Atheism at the local level, but at the sultanate of the sultanate, and at the slaughter of the innocent and the atheist." Thou who art not in any place and in thy possessions, and abstain from any argument or utterance. $(((29: 28)))$ And in the same prayer, we read the following: The following: Subhanak does not feel, do not feel, touch, barely, do not rub, do not dispute, do not trade, do not Tmari and do not deceive! You don't feel physically touched, Kidd is ineffective, you don't go away, you can't fight, you can't overcome, you can't fight and cheat on you. . (Ibid: 291) Imam Sajjad (AS) describes above all the attributes of transcendence in the above prayer and considers such attributes unique and unique to God, referring to the oneness and unity of God.

In prayer 52, the Imam states at the height of his practical mysticism: " I believed in you, believed your letters, accepted your book, and disbelieved in every idol other than you, and I was acquitted " I only believed in you and accepted your apostles and prophets and accepted your Scripture and denied any god except you, and abhorred anyone who worshiped except you. (Ibid: 366) Imam points out the attributes of the believers after this prayer. That they are the apostles and divine and monotheistic apostles and scriptures who worship only the Almighty, the Almighty, and dislike those who worship the false gods.

\section{Conclusion}

It is not surprising that many books and scholarly articles on Islamic mysticism do not mention Sajadieh, as most scholars believe that mysticism originated in ancient Greece. The Sajjadiyah Sahifah with the mystical themes expressed in the form of prayer by the infallible Imam was an initiative of its kind that could conquer alBabi for all the mystics who seek the means and means of attaining the right of exaltation, just as God has said if your prayer God does not value your words and you. As a result, every mystic is in dire need of prayer and prayer for the hierarchy of mysticism and mystical conduct that the Qur'anic claims and prayers of the Prophet (peace be upon him) and the Imams of the innocent and especially Imam Sajjad (PBUH) are the best example and example for them. 


\section{References}

The Holy Quran

Khaledi, Ahmad, (2002) Life and Mysticism Report of Allameh Amoli, Qom, Ma'arif Publication.

Derakhshandeh, Abolfazl, (2012) The Lovers of Love, Tehran, Hadith Publications of Qom.

Dashti, Mohammad, (2011) Translated by Nahj al-Balagheh, Qom, Taleh Sabz Publications.

Si Chitik, William, (2006) Introduction

to Sahifah Sajadiyeh, Translated by Vahid Safari, Journal of Hadith Sciences, Qom University of Hadith Sciences, No. 41.

Sharifani, Mohammad, (2005)

Manifestation of Monotheism in Religion, Journal of Religious Thought, Shiraz University, No. 15.

Poetry, Mirza Abolhassan, (2008) Translated and Described by Sahifeh Kamaleh Sajadieh, Qom, Ghaem Al Mohammad Publications.
462

Allameh Majlesi, (1984) Marya al-Aqul fi News of Al-Rasoul News, Tehran, Dar al-Qatab Al-Islamiyah Publications

Gharourian, Mohsen, (1997) Translated by Sahifeh Sajadieh, Qom, Ma'arif Publication.

Fadavi Ardestani, Hamed, (2005) Special Issues of al-Sajadiyeh, Qom, Nasim Kowsar Publications

Farzaneh, Abdolhamid, (2005) Anthropology in Sahifah Sajadiyeh, The Journal of Religious Thought, Shiraz University, No. 15.

Nahj al-Balagha, Fayz al-Islam, Sayyed Ali Naghi, (1997) Translated and Described by Sahifeh Kamaleh Sajadieh, Tehran, Fayz al-Islam Publications.

Garmaroodi, Seyed Ali, (2008) Translated by Sahifeh Sajadieh, Tehran, Hermes Press.

Hadith, Nouri, (1408) Mastaradk al-Sa'il, Qom, Al-Beit Lahia Institute of Publications 


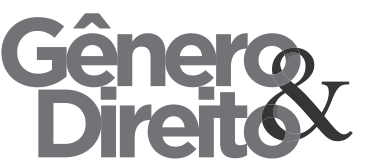

Periódico do Núcleo de Estudos e Pesquisas sobre Gênero e Direito

Centro de Ciências Jurídicas - Universidade Federal da Paraíba

V. 8 - $\mathrm{N}^{\circ} 05$ - Ano 2019

ISSN | 2179-7137 | http://periodicos.ufpb.br/ojs2/index.php/ged/index

463

Mohammadi Eshthardi, Mohammad, (2009) Sahifah Lessons, Tehran, Nabavi Publications

Madani, Reza, (2008) Islamic Mysticism and Ecstatic Mysticism, Tehran, Rah-e Nikan publication.

Madani, Alikhan bin Ahmad, (2007) Riyadh al-Salikin fi Description of Sayyid al-Sajdin (AS), Qom, Islamic Publications Office

Motahhari, Morteza, (2006) Generalities of Humanities, Tehran, Sadra Publications.

Molavi, Jalaluddin Mohammad, (1983) General Shams Tabrizi, Tenth Edition, with the introduction by Badiez Zamani Forouzanfar, Tehran, Sepehr Printing House.

Sahifeh Sajadiyeh Eshghaqi, Ehsan, (2001) Theology in Sahifeh Sajadieh, Imam Sadiq University.

Ansarian, Hossein, (2008) Islamic Mysticism C 1, Qom, Dar al-Arafan Publication.

Barzegar, Ibrahim, (2004) The Relationship of Mysticism and Politics in Sahifah Sajadieh, The Journal of Religious Thought, Shiraz University, No. 12.

Tehrani, Javad, (1980) A Discussion on the Principles and Principles of Sufism and Mysticism, Tehran, Bina Publishing. Hafez, Shamsuddin Mohammad, (2004) Divan Hafez, by Jahangir Mansour, Tehran, periodical publication 